\title{
IBADAH KONTEMPORER: SEBUAH ANALISIS REFLEKTIF TERHADAP HADIRNYA BUDAYA POPULER DALAM GEREJA MASA KINI
}

\author{
Yohanis Luni Tumanan ${ }^{1)^{*}}$ \\ ${ }^{1)}$ Mahasiswa Doktoral Sekolah Tinggi Theologia Jaffray \\ *Penulis korespondensi:hani_glorieslife75@yahoo.com
}

\begin{abstract}
Abstrak
Ibarat dua buah sisi mata uang, musik dan ibadah tidak dapat dipisahkan dalam sebuah tata ibadah gereja. Ibadah merupakan salah satu cara jemaat untuk berhubungan dengan Pencipta secara dramatis-simbolis. Thomas G. Long mengatakan bahwa konteks bergereja dewasa ini adalah perang gaya baru, yaitu perang ibadah. Fenomena ini dipengaruhi oleh derasnya arus "budaya pop" yang mampir dalam ibadah gereja, yaitu dengan munculnya Christian Contemporary Music (CCM). Hal ini ditandai dengan wajah segar dalam berbagai bidang pelayanan yang peka terhadap pasar (market sensitive) yaitu peka dengan keinginan orang-orang di zaman ini, termasuk ibadah yang ditata untuk menarik pengunjung gereja. Penggunaan musik Kristen kontemporer dengan peralatan combo band, gaya musik dan aransemennya seperti musik populer umumnya tersebut kemudian merefleksikan sebuah ibadah yang disebut sebagai ibadah kontemporer (contemporary worship) yang sifatnya dinamis dan penuh antusiasme. Namun, kita tidak boleh kehilangan nilai-nilai hakiki yaitu kebenaran Alkitab untuk menata dan mengembangkan ibadah gereja dalam menghadapi derasnya arus "budaya pop".
\end{abstract}

Kata-kata kunci: ibadah kontemporer, musik kristen kontemporer, budaya pop, gereja, musik

Like two sides of the same coin, music and worship in a church service cannot be separated. Worship is one way for the congregation to relate to the Creator in a dramatic-symbolic manner. Thomas G. Long declares that in the context of the contemporary church there is a new style war, that is the worship war. This phenomena has been influenced by the swift current of "pop culture" which made its appearancein church worship with the advent of Christian Contemporary Music (CCM). This brought a fresh face to various aspects of ministry which were market sensitive, that is sensitive to the desires of contemporary people, including worship services designed to attract church visitors. Contemporary Christian music uses a full band and the musical style and arrangements of popular music, which is reflected in a worship service called a contemporary worship service whose nature is dynamic and full of enthusiasm. Yet, the Christian church cannot lose essential values, such as using biblical truth as a basis for ordering and developing the church worship service, when facing of the swift current of "pop culture." 
Keywords: contemporary worship, Christian contemporary music, pop culture, church, music

\section{Pendahuluan}

Tulisan ini bertujuan melakukan analisis reflektif dalam ibadah kontemporer (contemporary whorship) yang merupakan salah satu cara kerja budaya populer dalam gereja masa kini. Oleh sebab itu analisis ini tidak dapat dipisahkan dari musik kontemporer. Budaya musik semakin berkembang dibandingkan sebelumnya. Perkembangan ini, selaras dengan perkembangan kebudayaan manusia. Selain itu, perkembangan musik sangat didukung oleh penemuan teknologi baru, di samping derasnya arus informasi dan komunikasi antar kelompok manusia di dunia ini.

Musik populer telah berkembang di abad ke-20 yang dibawa oleh Michael Jackson, Mariah Carey, Britney Spears, Ricky Martin, dan New Kids on the Block, maka orang-orang di seluruh dunia, terutama generasi mudanya cenderung menggunakan musik tersebut untuk berbagai kepentingan hidupnya. Musik memberikan peranan yang sangat penting dalam sejarah manusia khususnya gereja. Musik memiliki pengaruh yang sangat kuat bagi emosi manusia, karena musik dapat menjadi alat untuk merangsang emosi pendengarnya, memberikan inspirasi, mendorong ataupun sebaliknya dapat menjatuhkan.

Dalam ajaran agama Kristen, musik merupakan anugerah Allah kepada manusia. Allah menganugerahkan musik agar kita dapat menggunakannya dan mengembangkannya untuk mengungkapkan kreativitas kita dalam penyembahan dan ibadah manusia kepada Allah. Musik dan ibadah tidak dapat dipisahkan, musik berperan untuk menciptakan kesadaran akan kehadiran Allah dan suasana untuk ibadah, menghidupkan jiwa manusia, menyatukan jemaat dalam suatu pengalaman ibadah bersama dan menyatakan iman jemaat kepada Allah. Dengan kata lain, musik dapat menjembatani hubungan antara iman seseorang dengan perasaan dan sikap hidupnya.

Perkembangan musik gereja dalam agama Kristen dari waktu ke waktu semakin lama semakin berkembang fungsi dan strukturnya. Awalnya musik digunakan di Gereja Ortodoks dan Katolik. Pada masa Protestan ini berkembang, maka tradisi musik di Eropa terutama yang berbentuk koor (choir) dan berasas kepada harmoni, begitu berkembang pesat. Di dalam Gereja Protestan unsur-unsur musik Eropa juga muncul dalam teori dan praktiknya. Demikian juga yang terjadi di dalam aliran karismatik dan pentakosta, yang menurut penulis adalah trend setter ibadah kontemporer. 
Tulisan ini meninjau budaya populer (selanjutnya disebut budaya pop) secara konseptual dalam rangka membangun sikap yang relevan khususnya dalam konteks musik dalam ibadah gereja masa kini. Selain itu tulisan ini dilandasi oleh perhatian serius akan kenyataan adanya peranan atau pengaruh budaya pop yang sangat kuat dan signifikan dalam ibadah dan pelayanan gereja masa kini.

\section{Fenomena Budaya Populer Dalam Ibadah Kontemporer}

Konteks bergereja dewasa ini adalah "perang gaya baru," yaitu perang ibadah. ${ }^{1}$ Gereja-gereja kontemporer tampil dengan wajah segar dalam berbagai bidang pelayanan yang peka pasar (market sensitive), peka dengan keinginan orang-orang di zaman ini, termasuk ibadah yang ditata untuk menarik pengunjung gereja.

Tentu saja orang tidak sepenuhnya mengira bahwa penulis hendak beribadah ke gereja, jika penulis adalah anggota salah satu gereja aliran Pentakosta. Betapa tidak, segalanya disesuaikan. Sebagai contoh jemaat tidak lagi membawa Alkitab ke gereja. Beberapa kemungkinan jemaat tidak membawa Alkitab ke gereja, pertama: kenyataannya saat ini telah tersedia Digital Bible yang dapat dengan mudah di simpan di dalam telepon selular atau perangkat (gadget) lainnya, sehingga saat ibadah ketika pengkhotbah memerintahkan jemaat membaca firman Tuhan, kita mungkin akan melihat beberapa orang justru sedang mengutak-atik telepon selularnya (kemungkinan sedang mencari ayat tertentu). Yang kedua, di gereja karismatik tersedia in focus dengan screen yang siap menampilkan ayat-ayat yang sedang menjadi topik bahasan dalam khotbah, sehingga jemaat merasa tidak perlu membawa Alkitab dari rumah.

Dengan kapasitas gedung yang terbilang cukup besar, mampu menampung ribuan jemaat, tentu tidak mudah bagi pelayan untuk mengenal secara fisik maupun secara personal setiap jemaat yang hadir di ibadah. Salah satu pola gereja Karismatik (kontemporer) saat ini adalah jumlah jemaat yang super-besar (mega church), namun Wilfred J. Samuel mengungkapkan dalam gereja yang super-besar koinonia (persekutuan) tidak berfungsi dengan maksimal. ${ }^{2}$

Sisi lain yang menarik dalam ibadah kontemporer adalah terdapat panggung (stage) dalam istilah teologi disebut altar yang di atasnya terdapat podium kayu yang memiliki tanda salib di depannya seakanakan menegaskan bahwa kita sedang berada di gereja. Juga dilengkapi

${ }^{1}$ Thomas G. Long, Beyond the Worship Wars: Building Vital and Faithful Worship (Bethesta: Alban Institute, 2001), 50-51.

${ }^{2}$ Wilfred J. Samuel, Kristen Karismatik (Jakarta: BPK Gunung Mulia 2007), 43. 
seperangkat alat band dan sound system Electro Voice (EV) tergantung di langit-langit, juga terdapat beberapa kamera video profesional yang siap menampilkan jalannya ibadah ke dalam layar yang besar yang terpasang di atas mimbar. Semua perangkat hardware tadi mungkin biasa ditemukan dalam suasana konser artis-artis profesional, tetapi saat ini telah "mampir" di gereja. Kebaktian dimulai dengan doa, sang pemimpin pujian (worship leader) dan penyanyi latar (singer) $)^{3}$ bernyanyi diiringi oleh combo band dengan membawa pujian dan penyembahan ${ }^{4}$ yang dilantunkan secara berulang-ulang. Jemaat kemudian diundang untuk berdiri sambil bernyanyi, melompat, menari, bersalaman, bersorak karena gembira, menangis, mengepalkan, mengacungkan tangan, dan sebagainya. Sementara itu bagi anggota jemaat yang telah lanjut usia, diperbolehkan tetap duduk dan menikmati musik yang terkesan hingarbingar.

Ibadah berlangsung tanpa liturgi yang kaku, saatnya bagi pengkhotbah menyampaikan firman Tuhan, lalu pengkhotbah mulai naik ke altar, bernyanyi dan berdoa dengan suara ringan. Sambil menyapa jemaat, pengkhotbah mengeluarkan gadget pendukung dalam menyampaikan materi khotbah misalnya, Notebook, Handphone, I-Pad, Blackberry dan sebagainya. Sepanjang khotbah, diselingi beberapa nyanyian yang relevan dengan tema khotbah, menggunakan kisah-kisah kesaksian tentang kesembuhan, Roh Kudus, tentang berkat, menggunakan berbagai ilustrasi untuk menyampaikan firman Tuhan dan diselingi humor-humor untuk menghindari perasaan kantuk jemaat. Khotbah dilakukan dengan sangat sistematis, menyerupai orasi, berapiapi, suara yang menggelegar dan cenderung komunikatif dua arah dengan mengajak jemaat untuk berdialog.

Tulisan di atas sengaja penulis awali dalam topik ini untuk memberikan gambaran bagaimana ibadah dilakukan oleh gereja masa kini. Gambaran suasana ibadah persekutuan di atas mencerminkan sejumlah ciri khas gerakan dan persekutuan gereja Karismatik (kontemporer) yang juga dapat dijumpai di banyak tempat di seluruh belahan dunia. Perubahan-perubahan dan perkembangan-perkembangan yang terjadi dan dialami gereja selama ini merupakan sebuah sejarah yang sangat panjang selama \pm 2000 tahun. Sejarah gereja menceritakan

${ }^{3}$ Dalam lingkungan Karismatik istilah worship leader dan singer lebih populer digunakan, dan juga sudah digunakan oleh beberapa gereja lain yang non karismatik seperti beberapa gereja Evangelikal.

${ }^{4}$ Istilah pujian dan penyembahan dapat mengacu kepada sebuah bentuk pola ibadah dan repertoar lagu. Kata pujian atau penyembahan yang digunakan pada konteks yang berbeda memiliki arti yang berbeda pula. 
tentang kisah pergumulan antara Injil dengan bentuk-bentuk yang digunakan untuk mengungkapkan Injil tersebut.

Judul tulisan ini mendorong penulis dalam melakukan kajian bagaimana sebuah ibadah yang dilakukan di Gereja Kontemporer, yang memanfaatkan musik sebagai media unggul. Mereka mampu menangkap dengan baik sisi positif dari cara kerja budaya populer. Musik yang digunakan dalam ibadah Karismatik merupakan musik dengan gaya yang sangat berbeda dari gereja-gereja tradisional yang menggunakan himne. Kita melihat terjadi perkembangan perlakuan terhadap cara jemaat menyanyi dalam ibadah. Awalnya nyanyian jemaat dalam ibadah hanya mazmur ${ }^{5}$ saja, kemudian berkembang dengan adanya himne. Himne ${ }^{6}$ adalah nyanyian berbait dengan syair baru (bukan dari kitab suci).

Sebagai sebuah kehidupan bersama religius yang berpusat pada Kristus, gereja sarat akan aktivitas seni, khususnya musik. Sebagian besar dari hal tersebut termanifestasi dalam ibadah. Secara historis, gereja telah meyakini bahwa ibadah merupakan tindakan komunal yang ditawarkan dalam bentuk ucapan syukur sebagai pemberian kepada Allah, suatu penerimaan akan firman Allah dan berbagai anugerah dari Allah, juga sebagai tanggapan atas pemberian dari setiap orang, semua yang kurang dari itu bukanlah maksud sebenarnya dari ibadah itu sendiri.

David R. Ray mengatakan jika sebuah gereja ingin ibadahnya menjadi autentik dan kontekstual, ibadah tersebut haruslah merefleksikan bagaimana jemaat itu sesungguhnya. Suatu ibadah jemaat yang autentik merefleksikan siapa diri mereka secara kultural, waktu dan tempat mereka tinggal, dan iman dari hati dan pikiran mereka. Beribadah secara autentik dan kontekstual tidak semudah dan dapat diduga seperti dengan cara biasanya dilakukan atau seperti diambil dari buku salah satu denominasi, namun jauh lebih dapat dinikmati, diimani dan efektif. 7

Pola ibadah yang sifatnya liturgikal merupakan sesuatu yang telah lama menjadi pertentangan hangat bagi kaum gereja tradisional dan karismatik. Secara populer masyarakat awam mengartikan liturgi sebagai upacara gereja, atau tata cara ibadah gereja, dan sebagainya. Sangat berbeda dengan yang dilakukan oleh kalangan gereja-gereja

${ }^{5}$ Mazmur ialah doa gereja yang dinyanyikan. Oleh karena itu, Mazmur harus mendapat tempat liturgis sendiri di dalam ibadah. G.W. Oberman dkk. dalam J. L. Ch. Abineno, Unsur-Unsur Liturgia Yang Dipakai Oleh Gereja-Gereja di Indonesia (Jakarta: BPK Gunung Mulia, 2005), 70.

${ }^{6}$ Kata "himne" mempunyai arti yang sangat luas dan sulit untuk dispesifikasikan secara jelas. Namun untuk tulisan ini, cukup menyatakan bahwa penggunaan kata "himne" di sini mengacu pada tradisi musik jemaat dari Martin Luther dan para Reformator yang terus dikembangkan sampai pada hari ini.

${ }^{7}$ David R. Ray, Gereja Yang Hidup (Jakarta: BPK Gunung Mulia, 2000), 41. 
karismatik/kontemporer, musik dalam ibadah sifatnya lebih fleksibel, spontan, tidak dilakukan dengan struktur yang kaku. Inilah salah satu cara kerja budaya populer dalam pembentukan hegemoni dan pengaruh yang dahsyat bagi masyarakat sekarang.

Ketika gereja Karismatik menggunakan musik yang dikenal sebagai musik Kristen kontemporer (Christian Contemporary Music) dalam sebuah ibadah, kalangan gereja tradisional justru menganggapnya sebagai sebuah ketidakmengertian akan arti himne dan telah "mencuri kemuliaan Allah." Christian Music Contemporer identik dengan terminologi musik masa kini dengan perangkat musik combo band komplit. ${ }^{8}$ Penggunaan musik Kristen kontemporer dengan peralatan combo band, gaya musik dan aransemennya seperti musik populer umumnya tersebut kemudian merefleksikan sebuah ibadah yang disebut sebagai ibadah kontemporer (contemporary worship) $)^{9}$ yang sifatnya dinamis dan penuh antusiasme.

Kalangan industri rekaman di Indonesia, produser dan pengamat musik memberi label yang berbeda terhadap musik-musik yang memiliki pesan Injil, yakni menyebutnya sebagai musik atau rohani. Sedangkan untuk lagu atau musik yang bernafaskan Islam mereka menyebutnya sebagai musik atau lagu religi. Pembedaan ini selain untuk memberi klasifikasi juga lebih bertujuan kepada motif penjualan di pasar industri musik Indonesia.

Di luar dari perilaku penyanyinya, musik rohani merupakan musik yang mengandung nilai-nilai ibadah. Musik rohani adalah musik gerejawi, namun musik gereja adalah musik yang dipakai dalam ibadah gereja. Sementara itu kalangan gereja Karismatik memiliki pandangan yang berbeda terhadap musik-musik yang ada di luar gereja. Mereka menyebutnya sebagai musik "dunia" (sekuler) yang sangat berbeda tujuan dengan musik-musik Kristen kontemporer. Bagi sebagian orang sekilas tidak ada yang berbeda antara musik-musik Kristen kontemporer dengan musik-musik "dunia" tadi, baik dari segi instrumentasi maupun aspek musikal, seperti aransemen dan iramanya. Letak perbedaan yang signifikan justru hanya pada penggunaan lirik lagu tersebut.

Musik Kristen kontemporer cenderung menggunakan lirik-lirik alkitabiah yang diarahkan vertikal kepada Allah, sedangkan musik "dunia" menggunakan lirik-lirik yang lebih diarahkan horizontal kepada sesama manusia atau alam. Di dalam musik gereja penggunaan lirik yang alkitabiah mendapat perhatian khusus, karena melalui lirik tersebut

\footnotetext{
${ }^{8}$ Winardo Saragih, Misi Musik: Menyembah Atau Menghujat Allah? (Yogyakarta: Penerbit ANDI, 2008), 76.

${ }^{9}$ Ibadah kontemporer (contemporary worship) merupakan ibadah yang sifatnya lebih fleksibel dan tidak diatur dalam sebuah rutinitas yang tersusun secara liturgis.
} 
akan muncul interpretasi musikal yang akan menghidupkan lirik tersebut. Dengan kekuatan lirik akan terjadi "aklamasi" dan "proklamasi" tentang iman percaya di dalam nyanyian. Apakah musik kontemporer untuk ibadah gereja masih alkitabiah?

Dalam tulisan ini penulis mengulas unsur-unsur apa yang menjadikan sebuah lagu bisa dikatakan sebagai musik gerejawi. Karena penulis menemukan banyak kasus dalam lagu-lagu lain, sebagian orang menanggapi sebagai lagu rohani, sementara pihak lain tidak demikian. Seperti lagu Ruth Sahanaya "Kaulah Segalanya," atau lagu Josh Groban "You Raise Me Up" yang sering mampir di gereja. Hal ini bisa terjadi karena setiap pihak memiliki kriteria yang berbeda dalam memberi label terhadap sebuah lagu sehingga menjadi lagu rohani. Hal ini bisa saja akibat ketidakmengertian, minimnya pemahaman, atau karena batasan dan kriteria yang berbeda-beda pada institusi-institusi gereja sehingga belum ada kriteria yang "pas" dan dapat diterima banyak pihak untuk menentukan sebuah lagu rohani atau tidak.

Kajian lebih jauh juga penulis tujukan pada ibadah kontemporer saat dilakukan, kemudian melalui aktivitas ibadah tersebut akan terlihat begitu banyak kebudayaan-kebudayaan karismatik yang tertuang di dalamnya melalui penyajian-penyajian musik Kristen kontemporer. Adakah relevansi yang kuat antara refleksi kebudayaan Karismatik yang dilakukan jemaat dengan musik Kristen kontemporer, atau ibadah kontemporer sehingga muncul sebuah pola ibadah yang menurut Wilfred J. Samuel cenderung berkesan selebratif, "hingar bingar" dan antusias. ${ }^{10}$ Di mana dalam suasana yang selebratif jemaat merasa begitu dinamis serta aktif dalam ibadah termasuk melakukan gerakan-gerakan yang dilakukan atas tujuan tertentu. Perilaku jemaat dalam ibadah kontemporer sesungguhnya sangat dipengaruhi oleh kemampuan pemimpin pujian (worship leader), pemimpin musik (worship musician) membangun komunikasi yang aktif.

Worship leader merupakan pelayanan yang memerlukan kecakapan tersendiri, yang berbeda dengan pelayanan worship musician, pendeta, penatua atau penyanyi (singer). Worship leader memiliki beban yang berat untuk memimpin seluruh jemaat (mereka yang sakit, letih, sakit hati, keras kepala, malas, tak dapat diajar) ke dalam suatu suasana yang menciptakan hubungan dengan Allah baik secara pribadi maupun jemaat secara keseluruhan. Ada tiga tugas worship leader dalam sebuah ibadah kontemporer, yaitu: (l) membawa seluruh jemaat ke dalam hadirat Allah sehingga mereka dapat memuji dan menyembah-Nya dan mendengarkan-Nya dalam setiap ibadah; (2) mengoordinasi dan menyatukan para penyanyi dan pemain musik dalam pelayanan mereka

${ }^{10}$ Wilfred J. Samuel, Kristen Karismatik (Jakarta: BPK Gunung Mulia 2007), 68. 
kepada Allah dan dalam jemaat; (3) untuk mempersiapkan jemaat pada pelayanan firman Tuhan. ${ }^{\text {II }}$

Dari perspektif sosiologis, sebuah ibadah kontemporer menurut pandangan ilmu sosial merupakan sebuah pertunjukan seni (performing art) yang juga dengan mudah dipahami bagi pandangan masyarakat awam. Menyaksikan seseorang menyanyi (worship leader) di panggung diiringi oleh musisi yang memainkan seperangkat alat musik seperti, piano, synthesizer, gitar bas, drum dan beberapa penyanyi latar (backing vocal), sehingga orang yang mengikuti ibadah tersebut menyimpulkannya bahwa yang ia saksikan lebih menyerupai sebuah konser daripada sebuah ibadah di gereja yang selama ini ia kenal.

Dalam sebuah ibadah kontemporer, proses "membangun"mezbah ${ }^{12}$ bagi Tuhan melalui doa, pujian dan penyembahan yang dipenuhi atmosfer penyembahan yang intim dengan Tuhan dilakukan ketika lagu penyembahan pertama dinyanyikan. Atmosfer penyembahan adalah menciptakan atau membangun suasana dalam keintiman (intimacy) dengan Tuhan melalui musik sehingga menghadirkan suasana yang penuh dengan hadirat Tuhan (His presence). ${ }^{13}$

Atmosfer penyembahan dibangun melalui lagu-lagu penyembahan yang kemudian dilanjutkan dengan menggunakan sebuah pola akor penyembahan yang disebut flowing dilakukan berulang-ulang dengan dinamik yang bervariatif dengan mengundang Roh Kudus dan hadirat Tuhan memenuhi tempat ibadah tersebut. Selain itu penyajian musik dalam ibadah bersifat progresi akor, modulasi, open chord, slash chord, pemakaian nada dasar, improvisasi, pemakaian kode jari, pola ending dan sebagainya.

Seorang ahli musik gereja John F. Wilson ${ }^{14}$ mengatakan, tidak semua musik yang ditampilkan di gereja digunakan secara efektif bagi kemuliaan Tuhan. Beberapa cara membawakan musik tidak menyumbangkan apa-apa hanya sekedar atmosfer euphoria belaka, sementara yang lain melakukan sedikit lebih baik karena berhasil menggugah emosi jemaat.

\footnotetext{
${ }^{11}$ Mike dan Hibbert, Pelayanan Musik (Yogyakarta: Penerbit ANDI, 1988), 90.

12 "Mezbah" (the altar of God) merupakan tempat pertemuan manusia dengan Tuhan, di mana manusia menyembah dan menaikkan doa-doa kepada Tuhan dan Tuhan mencurahkan berkat-Nya (1 Raja-Raja 18:36-37). Mezbah juga sebagai dasar tempat korban diletakkan. Sebenarnya tubuh manusia juga adalah "mezbah" artinya setiap orang Kristen harus memberikan korban kepada Tuhan melalui puji-pujian.

${ }^{13}$ Kata "Hadirat" itu sendiri berbeda pengertian dengan hadir, Tuhan itu "Maha Hadir" (Omni Presence). Artinya Tuhan itu bisa berada di mana pun dan kapan pun Ia mau. Maksudnya, Dia memilih untuk ada secara nyata.

${ }^{14}$ John F.Wilson, An Intorduction to Church Music (Chicago: Moody Press, 1965), 18.
} 
Wilfred J. Samuel dalam bukunya Kristen Karismatik mengatakan bahwa musik dalam ibadah kontemporer cenderung overdosis atau berlebihan dalam ibadah. ${ }^{15}$ Memang pernyataan Wilfred sangat subjektif, namun penulis berharap pernyataan tersebut dapat menempatkan isu tentang musik yang menurut Wilfred overdosis tersebut pada perspektif yang tepat.

Ibadah kontemporer adalah berlabel Karismatik. Orang melihat karismatik sebagai individu-individu yang berorientasi pada pengalaman, imperialis dalam pandangan, elitis dalam sikap, tidak terkontrol dalam ibadah, dan bebas dari setiap pegangan nyata dari Alkitab yang lebih dari sekedar bukti teks. Gerakan Karismatik memiliki perkembangan yang pesat dan telah menjadi lebih beragam, sehingga akan menyesatkan untuk menempatkan mereka semua di bawah panji identik. $^{16}$

Tingkah laku yang demikian sangat melekat dengan orang-orang yang terlibat dalam gereja Karismatik. Saat istilah "kebudayaan" digunakan dalam konteks gereja karismatik, maka pribadi-pribadi dan kelompok-kelompok yang ada di dalamnya memiliki kebutuhan yang spesifik seperti gaya, ekspresi, sikap, yang mudah dikenali dan memberikan mereka image maupun identitas yang khas sebagai Karismatik. Contohnya, jemaat dalam lingkungan Karismatik sangat biasa menggunakan sapaan shalom ketika bertemu dengan yang lain, selalu berjabat tangan ketika bertemu dengan rekan-rekan, bahkan beberapa orang memandang memiliki sikap rohani yang lebih dari orang lain.

\section{Terminologi dan Konsep}

Untuk dapat lebih jauh mengulas arti dari tema tulisan ini, yaitu ibadah kontemporer sebagai akibat dari perkembangan budaya populer yang sudah "mampir" di gereja masa kini, maka akan dikemukakan terminologi dan konsep dari kata kunci, yakni: "budaya populer dan ibadah kontemporer" dengam maksud untuk menjelaskan bagaimana budaya populer memengaruhi secara khusus ibadah gereja masa kini. Terminologi dan konsep yang penulis gunakan dalam tulisan ini merujuk pada pengertian dan ideologi yang terkandung dalam budaya populer, maupun ibadah kontemporer.

${ }^{15}$ Lihat penjelasan Wilfred J. Samuel, Kristen Karismatik (Jakarta: BPK Gunung Mulia, 2007), 67-69.

${ }^{16}$ Pastor Gilley's March 1999, Thing on these Thing, IV No. 3, Mei-Juni 1999. 


\section{Istilah Budaya Populer}

Untuk membahas pengertian "budaya populer" ada baiknya kita pahami dulu tentang kata "budaya", dan selanjutnya tentang "pop". Selanjutnya untuk mendefinisikan budaya pop kita perlu mengkombinasikan dua istilah yaitu "budaya" dan "popular."

Pertama, budaya dapat digunakan untuk mengacu pada suatu proses umum perkembangan intelektual, spiritual, dan estetis. ${ }^{17}$ Mungkin rumusan ini merupakan rumusan budaya yang paling mudah dipahami, misalnya, kita bisa bisa berbicara tentang perkembangan budaya Eropa Barat dengan merujuk pada faktor-faktor intelektual, spiritual, estetis para filsuf besar, seniman, dan penyair-penyair besar.

Kedua, budaya berarti pandangan hidup tertentu dari masyarakat, periode, atau kelompok tertentu. ${ }^{8}$ Jika kita membahas perkembangan budaya Eropa Barat dengan menggunakan definisi ini, berarti kita tidak melulu memikirkan faktor intelektual dan estetisnya saja, tetapi juga perkembangan sastra, hiburan, olah raga, dan upacara ritus religiusnya.

Ketiga, selain itu Williams juga mengatakan bahwa budaya pun bisa merujuk pada karya dan praktik-praktik intelektual, terutama aktivitas artistik. ${ }^{19}$ Dengan kata lain, teks-teks dan praktik-praktik itu diandaikan memiliki fungsi utama untuk menunjukkan, menandakan (to signify), memproduksi, atau kadang menjadi peristiwa yang menciptakan makna tentu.

Dengan demikian jika berbicara tentang budaya pop, berarti menggabungkan makna budaya yang kedua dengan makna ketiga di atas. Makna kedua pandangan hidup tertentu memungkinkan kita untuk berbicara tentang praktik-praktik, seperti liburan ke pantai, dan aktivitas pemuda subkultur sebagai contoh-contoh budayanya. Semua hal ini biasanya disebut sebagai budaya-budaya yang hidup (lived cultures) atau bisa disebut sebagai praktik-praktik budaya. Makna ketiga, praktik kebermaknaan memungkinkan kita membahas tentang opera sabun, musik pop dan komik sebagai contoh budaya pop. Budaya ini biasanya disebut sebagai teks-teks budaya. Namun ada juga yang memakai definisi pertama Williams untuk budaya pop.

Sedangkan kata "pop" diambil dari kata "populer". Terhadap istilah ini Williams memberikan empat makna yakni: (1) banyak disukai orang; (2) jenis kerja rendahan; (3) karya yang dilakukan untuk menyenangkan orang; (4) budaya yang memang dibuat oleh orang untuk dirinya sendiri. ${ }^{20}$ Kemudian untuk

\footnotetext{
${ }^{17}$ Williams, Raymond, Keyword (London: Fontana, 1983), 90.

${ }^{18}$ Ibid., 90.

${ }^{19}$ Ibid.

${ }^{20}$ Ibid., 237.
} 
mendefinisikan budaya pop kita perlu mengkombinasikan dua istilah yaitu "budaya" dan "populer". Berdasarkan istilah Williams di atas maka arti budaya pop mempunyai titik awal yaitu:

Pertama, ada yang menyatakan bahwa budaya pop itu memang budaya yang menyenangkan atau banyak disukai orang. Kita bisa melihatnya lakunya lagu-lagu misalnya album pertama Peterpan (sebuah group band ternama yang pernah top). Kita juga bisa meneliti konser, pesta olahraga, festival. Kita bisa melihat kesukaan pendengar terhadap program TV melalui riset pasar. Dari pengamatan terhadap berbagai hal tersebut akan memberikan banyak informasi bagi kita. ${ }^{21}$

Kedua, untuk mendefinisikan budaya pop adalah dengan mempertimbangkan budaya tertinggal (rendah). Budaya pop menurut definisi ini merupakan kategori residual untuk mengakomodasi praktik budaya yang tidak memenuhi persyaratan budaya tinggi. Dengan kata lain budaya pop didefinisikkan sebagai budaya substandar.

Ketiga, mendefinisikan budaya pop sebagai "budaya massa." Definisi tersebut sangat tergantung pada definisi sebelumnya. Mereka menyatakan budaya pop adalah "budaya massa" dengan tujuan menegaskan bahwa budaya massa secara komersial tidak bisa diharapkan. Ia diproduksi massa untuk konsumsi massa. Pendengarnya adalah sosok-sosok konsumen yang tidak memilih. Budaya itu sendiri dianggap hanya sekadar rumusan, manipulatif.

Keempat, menyatakan bahwa budaya pop adalah budaya yang berasal dari "rakyat". Ia mengangkat masalah ini melalui pendekatan yang beranggapan bahwa budaya pop adalah sesuatu yang diterapkan pada "rakyat" dari atas. Budaya pop adalah budaya autentik "rakyat". Budaya pop seperti halnya budaya daerah merupakan dari rakyat untuk rakyat. Definisi pop dalam hal ini seringkali dikait-kaitkan dengan konsep romantisme budaya kelas buruh yang kemudian ditafsirkan sebagai sumber utama protes simbolik dalam kapitalisme kontemporer. ${ }^{22}$ Namun ada satu persoalan dengan pendekatan ini yakni pertanyaan tentang siapa yang termasuk dalam kategori "rakyat."

Persoalan lainnya adalah hakikat wacana dari mana asal-usul budaya itu terbentuk. Tidak peduli berapa banyak kita memakai definisi ini, fakta membuktikan bahwa rakyat tidak secara spontan mampu menghasilkan budaya dari dari bahan-bahan material yang mereka buat sendiri. Apapun budaya pop itu, yang pasti bahan mentahnya disediakan

\footnotetext{
${ }^{21}$ Untuk memahami lebih jelas mengenai hal tersebut dapat dibaca dalam buku Budaya Populer di Indonesia: Mencairnya Identitas Pasca-Orde Baru, editor oleh Ariel Heriyanto.

${ }^{22}$ Tony Bernet, Populer Culture: "Defining Our Terms," dalam Populer Culture: Themes and Issues I (Milton Keynes: Open University Press, 1982), 27.
} 
selalu secara komersial. Budaya populer yang juga disebut budaya massa adalah budaya yang dihasilkan melalui teknik-teknik industrial produksi massa yang diharapkan menghasilkan keuntungan sebanyakbanyaknya. ${ }^{23}$ David Jary dan Julia Jary dalam Collins Dictionary of Sociology mengatakan budaya massa adalah:

The relatively standardized and homogeneous cultural product, i.c. both goods and services and the associated cultural experiences, which are designed to appeal to the mass of the population. Mereka lebih lanjut mengatakan... One important conception of mass culture is the idea that goods mass produced for consumption (including even gramaphone records, reprints of great art, etc) provide inherently inferior experiences. ${ }^{24}$

Dari definisi di atas kita bisa memahami jika budaya massa dilihat sebagai produk budaya yang relatif terstandarisasi, diseragamkan untuk dikonsumsi oleh banyak orang, maka ada sebuah mekanisme yang bekerja pada skala global dalam praktik standarisasi tersebut. Ada mekanisme yang mengatur budaya massa sehingga bisa diterima oleh sejumlah orang dalam jumlah yang sangat besar.

Berdasarkan uraian yang ada, maka dapat disimpulkan bahwa budaya populer adalah budaya massa, yang mampu menciptakan daya tarik, disukai oleh banyak orang tanpa mengenal kelas sosial. Selain itu membangkitkan euphoria, dan dan dirancang untuk tujuan komersial. Sebagai hasil pengamatan dan analisis penulis dalam kaitan dengan ibadah gereja, sangat terlihat jelas bahwa lagu-lagu himne sudah tidak populer lagi dinyanyikan dalam jemaat apalagi generasi muda gereja. Namun lagu-lagu kontemporer dengan accord slash, penuh improvisasi musik yang diiringi combo band sangat membangkitkan daya tarik dalam ibadah gereja. Inilah realita yang kita jumpai dalam perubahan dan perkembangan dalam ibadah gereja masa kini. Dengan contoh ini, maka penulis berpendapat bahwa gereja Karismatik sangat berperan penting dalam perkembangan dan kemajuan ibadah kontemporer yang kita jumpai sekarang ini.

\section{Ibadah Kontemporer: Pola dan Pengaruhnya bagi Gereja}

Istilah kontemporer sendiri telah menimbulkan banyak polemik dan kesalahpahaman, sebenarnya istilah musik kontemporer sifatnya sangat luas. Ia tidak menunjuk kepada sesuatu apapun yang sifatnya spesifik, kecuali menunjukkan sesuatu yang kekinian atau mewakili masa kini

\footnotetext{
${ }^{23}$ Dwi Ratna Aprilia, "Iklan dan Budaya Populer: Pembentukan Identitas Ideologis Kecantikan Perempuan," diakses 20 Januari 2015, http://www.kompas.com/kompascetak/0305/05/swara/293908.htm.

${ }^{24}$ Tony Bernet, Populer Culture, 27.
} 
yang tidak dibatasi oleh periode waktu tertentu. ${ }^{25}$ Bila merujuk kata kontemporer adalah contemporare (Italia) dan contemporary (Inggris) yang secara harfiah berarti semasa atau sezamannya justru akan menimbulkan kebingungan bagi banyak orang awam. Istilah musik kontemporer hanya dapat dimengerti dalam konteksnya, berikut kutipan yang menjelaskan musik kontemporer menurut Suka Hardjana:

Secara spesifik, musik kontemporer hanya dapat dipahami dalam hubungannya dengan perkembangan sejarah musik Barat dan Amerika. Namun walaupun dapat mengacu pada sebuah pemahaman yang spesifik, sesungguhnya label kontemporer yang dibubuhkan pada kata seni maupun musik sama sekali tidak menunjukkan pada sebuah pengertian yang per definisi bersifat normatif. Itulah sebabnya, terutama bagi yang awam, seni atau musik kontemporer banyak menimbulkan kesalahpahaman yang berlarut-larut. ${ }^{26}$

Dalam transformasi sebuah zaman bila kita hubungkan dengan istilah kontemporer, sederhananya menjelaskan makna sebenarnya dari istilah musik kontemporer itu. Namun yang perlu dipahami bahwa, subjek dari musik kontemporer terletak pada wacana dan ciri-ciri musik masa kini tersebut. Musik kontemporer hanyalah sekelumit dari efek transformasi sebuah zaman yang sedang berlalu, sosoknya bersifat impermanent.

Bagi orang-orang yang saat itu maupun sekarang ini aktif dalam musik Kristen kontemporer masih terus memperjuangkan apa yang dahulu dirintis oleh tokoh pendirinya seperti, Larry Norman dan Chapter of Acts, ${ }^{27}$ yakni menjembatani antara musik gereja tradisional dengan musik kontemporer. Hal ini tampak mulai berhasil, karena banyak gereja, termasuk gereja tradisional, walaupun masih malu-malu, mulai menerima musik Kristen kontemporer. Gaya dari musik Kristen kontemporer dipengaruhi oleh musik populer dan tidak sesuai dengan organ gereja tradisional. Banyak gereja mengadopsi ibadah kontemporer, oleh karena itu mereka memiliki worship band atau praise band untuk digunakan selama ibadah mereka.

Namun bagaimana pun, beberapa band kontemporer Kristen juga tampil sebagai worship band dalam acara-acara tertentu diluar gereja, karena musik kontemporer Kristen pada hakikatnya berhubungan dengan industri musik rohani Kristen yang memiliki pasar cukup besar,

${ }^{25}$ Suka Hardjana, Corat-Coret Musik Kontemporer Dulu dan Kini (Jakarta: Ford Foundation dan Masyarakat Seni Pertunjukan Indonesia, 2003), 251.

${ }^{26}$ Hardjana, 252.

${ }^{27}$ Mark Allan Fowell, Encyclopedia of Contemporary Christian Music (Massachusetts: Hendrickson Publishers, 2002), 10. 
seperti di Indonesia perusahaan rekaman musik rohani Kristen yang cukup terkenal adalah Maranatha Records, Harvest Music, dan lain-lain.

Musik Kristen kontemporer yang sering digunakan dalam ibadah gereja lebih banyak berasal dari musisi Kristen kontemporer generasi yang baru seperti Don Moen, Michael W Smith (Amerika) dan Hillsong, Darlene Zschech (Australia) ${ }^{28}$ dan sebagian karya-karya mereka telah banyak diadaptasi ke dalam bahasa Indonesia dan digunakan dalam ibadah. Saat ini lagu puji-pujian tidak hanya berasal dari luar negeri, setelah banyak kebangunan rohani dan anak-anak Tuhan Indonesia mulai menggubah lagu-lagu pujian yang indah, yang dirasakan cocok dengan budaya, pengalaman, dan mudah mereka serap.

Lagu-lagu kontemporer sangat disukai dan cepat menjadi populer, seperti yang dihasilkan oleh Symphony Music, True Worshippers, GMB (Giving My Best), Frangky Sihombing, Jonathan Prawira, Niko Njotorahardjo, Ir. Welyar Kauntu, Djohan E. Handojo, Vetry Kumaseh, Sari Simorangkir dan lain-lain. Musik Kristen kontemporer yang digunakan di dalam ibadah kontemporer menggunakan musik yang berasal dari album-album rekaman seperti artis-artis rohani di atas. Tak seorang pun tahu seperti apa dan ke arah mana musik Kristen kontemporer akan terus mengalir dan menemukan tempatnya berlabuh. Bisa juga pertanyaan tersebut diabaikan, kecuali hanya menerima dan memahami bahwa musik dalam gereja juga tidak dapat terelakkan, tidak hanya sekedar ekspresi manusia terhadap sang pencipta, bukan sekedar keindahan, tetapi musik juga bagian dari bahasa kode hubungan dan kenyataan keseharian, bahasa industri pergaulan tanpa batas. ${ }^{29}$

Dalam kaitannya dengan budaya populer, maka menurut penulis musik Kristen kontemporer sebagai aksi maupun reaksi tumbuh dan berkembang dalam suasana dan lingkungan gereja, lintas denominasi dan komunitas Kristen tanpa batas dan untuk semuanya di zaman yang terus mengalami perubahan dan penuh kontroversi. Inilah filosofi dan cara kerja budaya populer dalam konteks ibadah gereja masa kini. Penulis sependapat dengan apa yang dikatakan oleh David Willoughby, bahwa musik memengaruhi dan dipengaruhi oleh perkembangan dan gaya baru dari musik populer komersil Contemporary Christian Music (Musik Kristen Kontemporer) dan "Gospel Rock."30

Selanjutnya ibadah kontemporer (contemporary worship) adalah bentuk ibadah Kristen yang muncul di abad ke-20. Ibadah kontemporer awalnya terbatas hanya dalam Gerakan Karismatik, namun sekarang

28 "Replacing Hymns with Contemporary Praise Music," diakses 21 Januari 2015, http://www.villyninablogspotcom.blogspot.com/2012_02_01_archive.html.

${ }^{29}$ Suka Hardjana, 257.

${ }^{30}$ David Willoughby, The World of Music 3rd Edition (Brown \& Benchmark Publisher, Susquehanna University, 1996), 53. 
telah ditemukan dalam berbagai gereja secara luas, termasuk beberapa gereja yang tidak berjalan dalam teologi karismatik. Ibadah kontemporer umumnya dikarakteristikkan oleh penggunaan musik penyembahan kontemporer dalam bentuk yang lebih informal. Jemaat menyanyi dengan khas dan dalam porsi yang lebih banyak. Ketika ibadah kontemporer dipraktikkan di gereja dengan tradisi yang liturgikal dalam tradisi liturgis, elemen dari liturgi sangat sedikit digunakan. Terminologi historic worship, tradisional worship atau liturgical worship kadang-kadang digunakan untuk menjelaskan bentuk ibadah yang konvensional dan mereka dibedakan dari bentuk ibadah kontemporer. Berdasarkan sejarah, fenomena ibadah kontemporer muncul dari Gerakan Bagi Yesus (Jesus Movement) di Amerika Utara pada tahun 1960-an dan gerakan Charismatic Renewal Movement di Australia dan New Zealand sepanjang tahun 1970-dan 1980-an. ${ }^{31}$ Fungsi musik dalam pelayanan, gaya lagulagunya, penampilan mereka, lirik-lirik yang secara eksplisit berisi teologi, dan teologi menyatakan secara tidak langsung melalui aspekaspek tersebut, hal ini yang membedakan ibadah kontemporer (contemporary worship) dari ibadah tradisional (traditional worship) dalam praktik dan latar belakang teologi.

Musik dalam ibadah kontemporer memiliki peran yang signifikan sepanjang ibadah dan ada pengulangan kalimat-kalimat yang menguatkan isi teologis dalam ibadah. Pengaruhnya yang kuat akan meningkatkan iman keyakinan seseorang juga sangat jarang menggunakan doa-doa yang formal (doa liturgikal). Secara teologis, musik dalam ibadah kontemporer dipengaruhi oleh aliran Pentakosta Karismatik dan kemudian berkembang dalam gereja Evangelical Theologies. Bagaimanapun fenomena ini telah memberi pengaruh kepada semua denominasi moyoritas dalam beberapa lapisan.

Ibadah kontemporer bertujuan sebagai wadah jemaat berkomunikasi dengan Pencipta, fakta sosialnya tidak terlepas dari musik sebagai media doa yang dipanjatkan. Musik dalam ibadah secara fungsional berarti bermanfaat bagi sesuatu, dalam sosiologi berkaitan dengan tindakan manusia, yang selalu merupakan tindakan yang bertujuan tertentu, tanpa mempersoalkan apakah tujuan itu disadari atau tidak, sehingga jelas bahwa musik dalam ibadah kontemporer dilakukan untuk tujuan-tujuan tertentu yakni berkomunikasi dengan Allah, yang dilakukan secara sadar maupun tidak. Musik Kristen

31 "Asal Usul Musik Kontemporer," Majalah Praise, diakses 24 Januari 2015, http://www.majalahpraise.com/asal-usul-musik-kontemporer-586.html. 
Kontemporer (Christian Contemporary Music) atau $\mathrm{CCM}^{32}$ ada kalanya disebut "inspirational music" adalah genre dari musik populer modern yang secara lirik, fokus kepada persoalan iman Kristen. Saat ini, istilah tersebut khusus digunakan mengacu kepada pop, rock Nashville, Tennesee dan industri musik dalam seremoni ibadah Kristen. Musisi seperti Avalon, Barlow Girl, Jeremy Camp, Casting Crowns, Amy Grant, Jars of Clay, Michael W Smith, Toby Mac, Rebecca St. James dan lainlain bebarapa yang mewakili dari genre ini hingga sekarang. ${ }^{33}$ Pada tahun 1960-an dianggap sebagai awal perpaduan musik modern dengan pelayanan Kristen. Bentuk musik ini dipelopori dan didukung para musisi Kristiani yang memiliki kerinduan menjangkau kaum muda dan memperkenalkan Yesus melalui musik yang bergaya sekuler. Saat itu merupakan awal dari musik Kristen kontemporer mulai dikenal sebagai sebuah genre musik secara resmi.

\section{Refleksi Teologis}

Menurut pandangan penulis, seperti apa yang telah diuraikan sebelumnya bahwa ibadah kontemporer adalah salah satu pola atau bentuk budaya populer yang pesat perkembangannya saat ini. Sudah tentu lagu rohani yang mengikuti corak budaya populer cocok dengan fenomena kultur yang ada. Lagu rohani kontemporer dapat beradaptasi dalam budaya pop karena lagu tersebut berbasis kultur postmodern. Penilaian yang menekankan emosi, intuitif, populer, dan tidak harus menekankan seni musik yang tinggi, telah mendorong lagu rohani kontemporer menjawab kebutuhan kultur masa kini. Selain itu, keterlibatan tokoh, media elektronik dan informatika (TV/radio /cassette), telah mendorong lagu rohani kontemporer memiliki banyak penggemar (menarik massa).

Bagaimana respons kita terhadap fenomena kultur ini? Apakah kita akan menyesuaikan diri dan tenggelam di dalamnya; ataukah kita akan mengambil sikap konfrontasi? Atau kita mencoba mengambil sisi positif dari era postmodern ini? Hal ini tentu saja memerlukan pertimbangan teologis, filosofis dan wawasan yang lebih mendalam tentang kebudayaan manusia di hadapan Allah. Namun secara sederhana Joachim Huang menegaskan bahwa, dalam menghadapi arus budaya

\footnotetext{
${ }^{32}$ Istilah Christian Music Contemporer dianalogikan sebagai jenis musik gereja yang di luar kaidah-kaidah musik maupun instrumentasi gereja tradisi yang menggunakan musik bergaya himne diiringi piano, organ dan sebagainya dalam setiap ibadah.

33 "Asal usul Musik Kristen Kontemporer," diakses 24 Januari 2015, http:/hypernet-arie.blogspot.com/2013/05/musik-kontemporer.html.
} 
populer, kita wajib menggantungkan diri pada tali keimanan yang yang berpangkal pada genggaman kuat Tuhan Allah Juruselamat sejati. ${ }^{34}$

Ada penilaian yang menempatkan budaya populer sebagai budaya yang berbahaya, yang sudah tercemar oleh dosa, seolah-olah tidak pantas hadir dalam ibadah gereja. Seperti dinyatakan oleh Francis A. Schaeffer dalam bukunya yang terkenal Escape From Reason, bahwa segala produk seni budaya, termasuk di dalamnya seni modern, musik, literatur dan film sudah terkena dampak kerusakan akibat dosa manusia; bahkan bidang sains, alam filsafat dan teologi pun tak luput dari imbasan dosa. ${ }^{35}$ Selanjutnya pengamatan A. W. Tozer yang mengatakan:

Penduniawian (proses sekularisasi) adalah salah satu bagian yang telah diterima sebagai gaya hidup masa kini. Cita rasa agamawi kita lebih dititikberatkan pada perkara sosial daripada yang rohaniah. Kita telah kehilangan seni keindahan beribadah. Kita tidak lagi menghasilkan orang orang saleh. Model-model figur kita adalah orang-orang yang sukses dalam dunia usaha, para atlit yang digandrungi serta tokoh tokoh pribadi teatris (seperti budaya massa yang melahirkan anaknya si Jacko (sebutan untuk selebritis Michael Jackson). Rumah-rumah kita sudah disulap menjadi teater-teater (tempat menikmati tontonan dengan iringan musik yang merdu). Bacaan-bacaan kita menjadi semakin dangkal serta himnologi (kidung pujian) kita telah terhempas pada batas-batas pencemaran terhadap yang suci, yang bernilai sakral. Dan yang paling celaka: tampaknya jarang ada orang yang mau prihatin. ${ }^{36}$

Meskipun dari sudut pandang yang lain, pernyataan Schaeffer dan A.W. Tozer terkesan subjektif, namun penilaian mereka terhadap arus budaya zaman adalah benar, jika ditempatkan padan porsi yang tepat, sesuai duduk perkaranya. Namun budaya populer tidak semata-mata dilihat dari satu sudut pandang saja. Sebab setiap arus budaya zaman selalu berdampak positif dan negatif, tergantung si penerima budaya tersebut.

Menilai arus budaya populer khususnya dalam konteks ibadah kontemporer, menurut penulis, justru memiliki peran positif yang membawa perkembangan dan kemajuan gereja dalam berbagai aspek pelayanan dan eksistensinya. Musik yang memiliki daya tarik dan improvisasi yang sesuai telah membangkitkan hubungan yang baru dan iman yang kental kepada Tuhan. Budaya populer harus dipandang secara netral, lalu memutuskan dengan tepat apa yang salah dan apa yang benar

${ }^{34}$ Joachim Huang, "Budaya Populer", Jurnal Pelita Zaman Volume ll No. 2 Tahun 1996, diakses 20 Januari 2014, http://alkitab.sabda.org/resouce.php?res=jpz\&

topic $=699$

${ }^{35}$ Ibid.

${ }^{36}$ Ibid. 
sesuai dengan firman Tuhan. Kita sependapat dengan Joachin Huang tentang cara menghadapi arus budaya populer yaitu metode komplementer: "preventif dan kurasi." konstruktif, dan kreatif) berurusan dengan segala tindakan pencegahan ekses-ekses negatif sedini mungkin artinya mengefektifkan seluruh kemampuan dan kearifan untuk menahan serangan bertubi-tubi nilainilai perubahan dalam segenap aspek kebudayaan. Selanjutnya metode kuratif, yakni sikap dan semangat memperbaiki kondisi yang buruk dengan pilihan yang paling bijak demi membuahkan kebajikan terbesar. Pada prinsipnya, kita mungkin membaharui baik manusia, relasi antar personal, lingkungan hidup, kondisi masyarakat, sistem mekanisme, pola kecenderungan maupun praktik-praktik perilaku yang muncul sebagai dampak buruk akibat budaya zaman. Jadi budaya populer melalui musik kontemporer yang hadir dalam gereja sekarang mestinya dilihat sebagai peluang sekaligus tantangan di tegah-tengah arus budaya zaman.

\section{Kesimpulan}

Meskipun ada keterbatasan tertentu dalam tulisan singkat ini, namun setidaknya sudah mengupas apa yang menjadi inti permasalahan pada arus budaya zaman, yaitu ibadah kontemporer sebagai imbas dari percikan dan pengaruh budaya populer yang sudah lama mampir dan diterima oleh gereja, sekalipun di dalamnya terkandung esensi dan tendensi yang mungkin saja menyimpang dari ajaran firman Tuhan. Namun demikian harapan penulis adalah agar setiap orang Kristen mempunyai sikap optimisme dan memandang budaya populer dari sudut pandang positif, sehingga dapat menerima yang positif sebagai media komunikasi yang efektif bagi kemajuan pelayanan gereja pada masa yang akan datang. Penulis melihat beberapa asumsi mendasar dari musik budaya pop dalam ibadah kontemporer sebagai berikut.

Pertama, musik dalam ibadah kontemporer memiliki side effect yang akan menstimulus perasaan dan fisik jemaat yang ada, kemudian secara psikologis menimbulkan pengaruh timbal balik (mutual influence) sehingga akan merefleksikan berbagai kebudayaan karismatik di dalam ibadah yang kontemporer tersebut.

Kedua, musik Kristen kontemporer dan ibadah kontemporer merupakan interpretasi dan pengembangan apa yang terdapat dalam Mazmur jika dihubungkan dengan konteks masa kini. Jadi Mazmur

${ }^{37}$ Metode tersebut di atas adalah saran dari Joachin Huang dalam tulisan sebuah artikel: Budaya Populer yang telah dimuat dalam Jurnal Pelita Zaman Volume 11 No. 2 Tahun 1996. 
sebagai basic musik kontemporer yang sudah mngalami interpretasi dan improvisasi yang perkembangannya pesat hingga sekarang.

Ketiga, dalam konteks kekinian, musik Kristen kontemporer dan ibadah kontemporer merupakan implikasi dari apa yang dipraktikkan dalam Mazmur. Ibadah kontemporer dengan berbagai refleksi kebudayaan Karismatik telah menjadi tools bagi jemaat untuk memenuhi kebutuhan spiritual mereka.

Akhirnya dapat disimpulkan bahwa apa pun bentuk dari budaya populer, termasuk musik Kristen kontemporer pada dasarnya mengandung sebuah nilai hegemoni terhadap masyarakat postmodern. Hegemoni dapat diartikan suatu cara penerapan praktik-praktik kekuasaan ideologi yang tak terlihat atau tersembunyi dan tak disadari keberadaannya dalam lingkungan masyarakat. Hegemoni juga bisa diterjemahkan sebagai suatu proses-proses atau praktik-praktik sosial dengan segala macam ide yang telah terkonstruksi sebagai milik satu kelompok kelas dominan atau kelas-kelas berkuasa yang ada dan mempunyai kekuatan untuk memengaruhi hati dan pikiran seseorang dalam lingkungan masyarakat.

\section{Kepustakaan}

Abineno, J. L. Ch. Unsur-Unsur Liturgia Yang Dipakai Oleh Gereja-Gereja di Indonesia. Jakarta: BPK Gunung Mulia, 2005.

Aprilia, Dwi Ratna, "Iklan dan Budaya Populer: Pembentukan Identitas Ideologis Kecantikan Perempuan.” Diakses 20 Januari 2015. http://www.kompas.com/kompas-cetak/0305

/05/swara/293908.htm.

“Asal Usul Musik Kontemporer”. Majalah Praise. Diakses 24 Januari 2015. http://www.majalahpraise.com/asal-usul-musik-kontemporer586.html.

Bernet, Tony. Populer Culture: Themes and Issues I. Milton Keynes: Open University Press, 1982.

Fowell, Mark Allan. Encyclopedia of Contemporary Christian Music Massachusetts: Hendrickson Publishers, 2002.

Hardjana, Suka. Corat-Coret Musik Kontemporer Dulu dan Kini. Jakarta: Ford Foundation dan Masyarakat Seni Pertunjukan Indonesia, 2003.

Huang, Joachim. "Budaya Populer," Jurnal Pelita Zaman Volume 1l, no. 2 (1996). Diakses 20 Januari 2015. http://alkitab.sabda.org/ resource.php?res=jpz\&etopic=699.

Heriyanto, Ariel. Budaya Populer di Indonesia: Mencairnya Identitas PascaOrde Baru. Yogyakarta: Jalasutra, 2012. 
Long, Thomas G. Beyond the Worship Wars: Building Vital and Faithful Worship. Bethesta: Alban Institute, 2001.

Mike dan Hibbert. Pelayanan Musik. Yogyakarta: Penerbit ANDI, 1988.

"Musik Kontemporer." Diakses 24 Januari 2015. http://hypernetarie.blogspot.com/2013/05/musik-kontemporer.html.

Pastor Gilley's March. Thing on these Thing, IV No.3, Mei-Juni 1999.

"Replacing Hymns with Contemporary Praise Music." Diakses 21 Januari 2015. http://www.villyninablogspotcom.blogspot.com/2012_02_ 0l_archive.html.

Samuel, Wilfred J. Kristen Karismatik. Jakarta: BPK Gunung Mulia, 2007.

Saragih, Winardo. Misi Musik: Menyembah Atau Menghujat Allah. Yogyakarta: Penerbit ANDI, 2008.

Seay, Albert. Music in the Medieval World. Englewood Cliffs, New Jersey: Prentice-Hall, 1975.

Williams, Raymond. Keyword. London: Fontana, 1983.

Willoughby, David. The World of Music 3rd Edition. Brown \& Benchmark Publisher, Susquehanna University, 1996.

Wilson, John F. An Intorduction to Church Music. Chicago: Moody Press, 1965. 